
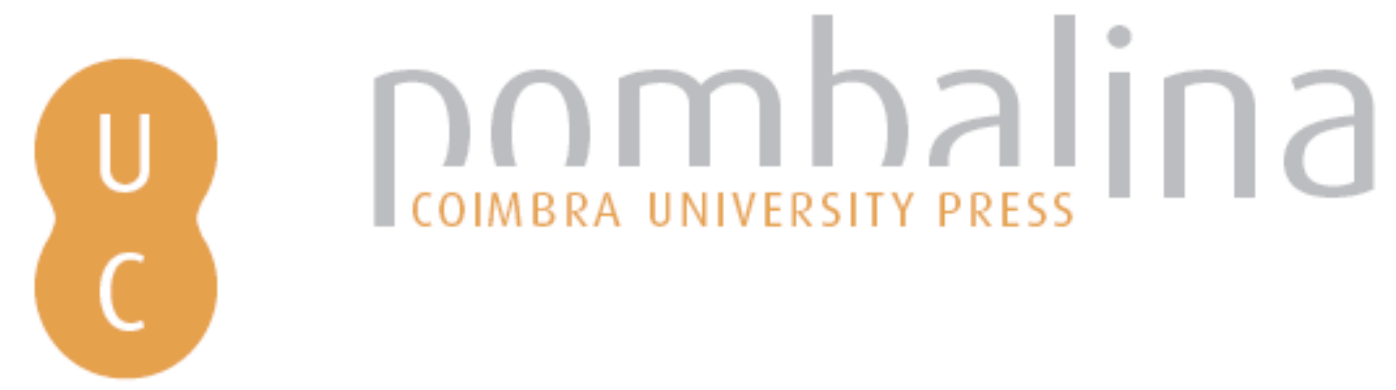

\title{
Semi-empirical fire spread model for chamise and big sagebrush shrubs with spatially-defined fuel elements and flames
}

Autor(es): $\quad$ Shen, Chen; Fletcher, Thomas H.; Weise, David R.

Publicado por: Imprensa da Universidade de Coimbra

URL

persistente: URI:http://hdl.handle.net/10316.2/44587

DOI: $\quad$ DOI:https://doi.org/10.14195/978-989-26-16-506_70

Accessed : $\quad$ 26-Apr-2023 14:30:40

A navegação consulta e descarregamento dos títulos inseridos nas Bibliotecas Digitais UC Digitalis, UC Pombalina e UC Impactum, pressupõem a aceitação plena e sem reservas dos Termos e Condições de Uso destas Bibliotecas Digitais, disponíveis em https://digitalis.uc.pt/pt-pt/termos.

Conforme exposto nos referidos Termos e Condições de Uso, o descarregamento de títulos de acesso restrito requer uma licença válida de autorização devendo o utilizador aceder ao(s) documento(s) a partir de um endereço de IP da instituição detentora da supramencionada licença.

Ao utilizador é apenas permitido o descarregamento para uso pessoal, pelo que o emprego do(s) título(s) descarregado(s) para outro fim, designadamente comercial, carece de autorização do respetivo autor ou editor da obra.

Na medida em que todas as obras da UC Digitalis se encontram protegidas pelo Código do Direito de Autor e Direitos Conexos e demais legislação aplicável, toda a cópia, parcial ou total, deste documento, nos casos em que é legalmente admitida, deverá conter ou fazer-se acompanhar por este aviso. 


\section{ADVANCES IN}

\section{FOREST FIRE RESEARCH}

\section{8}

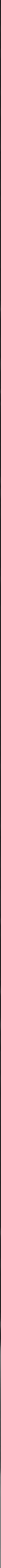




\title{
Semi-empirical fire spread model for chamise and big sagebrush shrubs with spatially-defined fuel elements and flames
}

\author{
Chen Shen ${ }^{1}$; Thomas H. Fletcher ${ }^{1 *}$; David R. Weise ${ }^{2}$ \\ ${ }^{1}$ Chemical Engineering Dept., Brigham Young University. Provo, Utah, USA 84602, \\ \{yourjj@gmail.com,tom_fletcher@byu.edu*\} \\ ${ }^{2}$ USDA Forest Service, PSW Research Station. 4955 Canyon Crest Dr., Riverside, California, USA \\ 92507, \{dweise@fs.fed.us\}
}

\begin{abstract}
Current operational fire spread models are mostly based on experimental results from dead, low moisture fuel beds and thus do not perform well when modeling fire behavior in live shrubs. Although computational fluid dynamics (CFD) models predict more reliable combustion behavior, they have a high computational cost, large grid sizes for landscape-scale simulations, and oversimplified combustion within a shrub. There is a need for intermediate-scale shrub combustion models that describe better solid fuel combustion properties and shrub architecture, which may serve as sub-grid models for landscape fire spread simulations. A previously-developed semi-empirical shrub combustion model was improved and expanded to treat live chamise and big sagebrush. Fire spread in live chamise and big sagebrush shrubs was measured in an openroofed wind tunnel at the Pacific Southwest Research Station in Riverside, CA, which was used as the basis to develop the current model. Wind speed was held constant at $1.4 \mathrm{~m} / \mathrm{s}$. Fuel segment placement was modeled by coupling a Lindenmayer systems (L-systems) approach with LiDAR scan data. Species specific correlations for physical properties and combustion characteristics of individual fuel element were developed from individual leaf combustion experiments with a flat-flame burner system. These were incorporate in this model to simulate individual leaf flames, whose combustion history were updated every time step and further checked in flame merging sub-model to group flames and propagate flames to neighboring leaves. Fire spread in the shrub was completed when the number of burning leaves reached a minimum threshold.

Bulk density and local fuel density were found to be two major factors in shrub flame propagation. The modeling results included flame height above the shrub, fraction of shrub burned, burn time, etc. Modeling results compared well with measured time-dependent fire behavior in the wind tunnel. Fuel element placement in the semi-empirical shrub combustion model was improved when a combined L-systems and LiDAR approach was used to describe shrub architecture. This coupled architecture approach resulted in the most consistent and best predictions of combustion behavior for most experiments as compared to other random fuel element placement approaches. Variations in local fuel density affected flame spread more than the overall fuel bed density. Combustion temperature correction and species sensitive flame merging algorithm further improved the accuracy of modeling results. This model is an innovative approach to simulate shrub combustion via flame propagation at individual fuel element scale with a fairly low computational cost.
\end{abstract}

Keywords: shrub combustion, live shrubs, wildland fire, modeling

\section{Introduction}

Most current operational fire spread models (e.g. BehavePlus, FARSITE, FlamMap) (Andrews 1986; Finney 1998; Finney 2006) are based on the semi-empirical model by Rothermel (Rothermel 1972), which was developed for dead or low-moisture single-layer fuels that are contiguous to the ground. These models do not adequately describe fire spread in live shrub fuels and development of a next-generation model is hindered by the lack of fundamental understanding regarding fire behavior in live fuels (Finney et al. 2013). Computational fluid dynamics (CFD) models, including FIRETEC and WFDS (Linn 1997; Mell et al. 2007), solve the governing equations for mass and energy balances 
and thus provide insight into the physics and chemistry that influence fire spread. However, these models are computationally expensive and are generally constrained to $\sim 8 \mathrm{~m}^{3}$ grid cells for landscapescale simulations, oversimplifying the combustion process. Additionally, CFD models are restricted by inadequate knowledge regarding solid fuel physical properties and surface reactions.

This paper describes a semi-empirical, multi-leaf shrub combustion model for big sagebrush (Artemisia tridentata) and chamise (Adenostoma fasciculatum), which is developed to help fill the gap between current operational models and CFD models. This model is based on individual leaf combustion behavior measured with a flat-flame burner (Prince 2014; Gallacher et al. 2017; Shen 2018). Flames are simulated using equations based on individual leaf properties and combustion behavior; fire spread is accomplished via flame-fuel overlap. Fuel element placement is described by plant architecture sub-models developed for these two species.

\section{Methods}

\subsection{Shrub Combustion Experiment}

Multi-shrub combustion experiments were performed in an open-roofed wind tunnel at the USDA Forest Service Pacific Southwest Research Station. The fuel bed in the wind tunnel was designed to contain two shrubs arranged naturally. Geometric dimensions of the shrubs were measured manually and by pictures taken from different angles. LiDAR (Light Detection and Ranging) scans were also performed in some experiments to establish a 3-D voxel data matrix of potential fuel element locations. Excelsior placed just upwind of the first shrub was used as the shrub ignition source. The first shrub (i.e., ignition shrub) propagated the fire to the second shrub, with the goal of measuring fire behavior with minimal influence from the excelsior. Wind speed was held constant at $1.4 \mathrm{~m} / \mathrm{s}$. Combustion characteristics and time-dependent fire behavior were measured using three digital camcorders at different locations around the fuel bed. Flame angle, fire propagation path, time to burnout and flame length were then determined from video images. The effect of a surface fuel under the shrubs was also explored in some experiments. Sagebrush was collected on the San Bernardino National Forest and chamise was harvested from North Mountain Experimental Area near Riverside, CA.

\subsection{Individual Leaf Combustion Experiment}

Individual combustion experiments with live fuel particles were conducted for various plant species in a flat-flame burner (FFB) system (Prince 2014; Gallacher et al. 2017; Shen 2018). The FFB has a porous surface and produces a $1 \mathrm{~mm}$ thin premixed flame $\left(\mathrm{CH}_{4}, \mathrm{H}_{2}\right.$ and air). A glass cage surrounding the FFB prevents entrainment of ambient air. The fuel samples were placed $5 \mathrm{~cm}$ above the burner surface and ignited by the post-flame convective gases $\left(1000^{\circ} \mathrm{C}, 10 \mathrm{~mol} \% \mathrm{O}_{2}\right)$. Moisture content and geometric dimensions of each fuel sample were measured. The sample was held above the burner by a rod connected to a cantilever mass balance and were measured continuously. A K-type thermocouple was used to measure the gas temperature. Leaf sample combustion from ignition to burnout was recorded by a video camera. Combustion characteristics (e.g. flame height, time to ignition, burnout time, etc.) were determined by image analysis using MATLAB code, and then correlated vs. species, moisture content, fuel element dimensions, etc. (Shen 2017).

\subsection{Shrub Structure Modeling}

Geometrical constructions of chamise and big sagebrush were simulated by coupling an L-systems (Lindenmayer systems) approach with LiDAR data (Shen et al. in preparation). The resulting plant architecture model simulated all the branch and individual fuel segment positions, tuned for the specific shrub samples studied. Individual fuel segment physical properties and combustion characteristics were subsequently generated from statistical, species-specific correlations developed from individual leaf combustion experiments. The axiom string types were formulated for chamise 
and big sagebrush to create primary branches in the shrub. Mass measurements were used to develop correlations to predict shrub fuel mass. Individual fuel elements with physical properties populated by statistical models developed were placed onto the primary branches. The number of segments was adjusted to satisfy the targeted total dry mass of foliage and stems less than $1 / 4$ inch. The ultimate direction of the L-systems strings for branches was guided by the location of the densest voxels from the LiDAR data. The resulting structure model predicted all the branch and segment positions, tuned for the specific shrub samples studied. Simulated shrubs appeared visually similar to the sampled shrubs and also generally matched the geometrical dimensions, as shown in Figure 1.
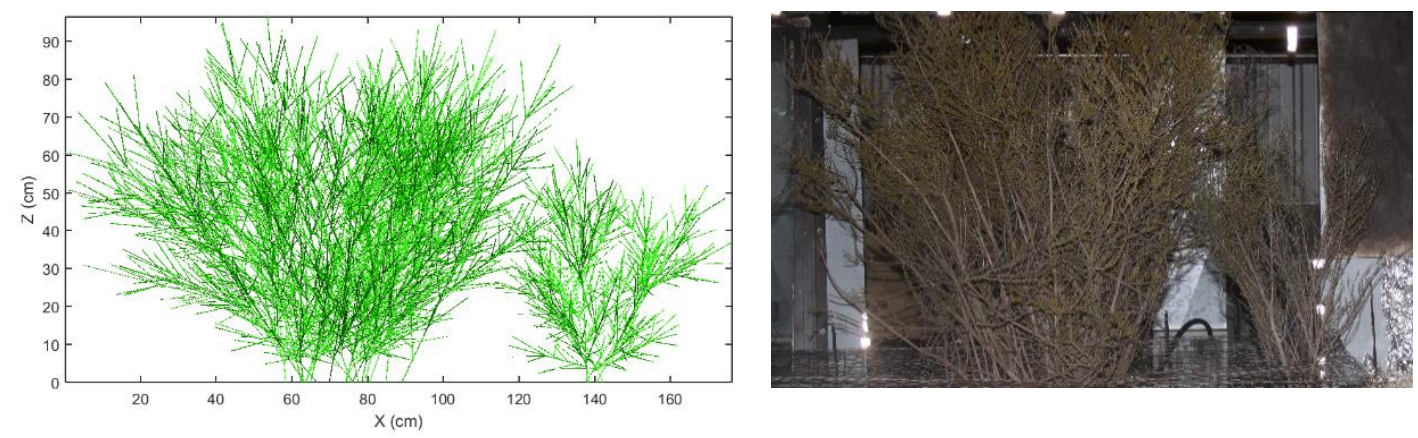

Figure 1 - A simulated chamise shrub set compared to the corresponding picture.

\subsection{Shrub Combustion Modeling}

The semi-empirical multi-leaf shrub combustion model includes the following modules: fuel element location, fuel element physical properties, fuel element combustion behavior, individual flame volume simulation, and flame merging. First, geometrical constructions of chamise and big sagebrush were simulated to establish fuel element placement. Individual segment flame volume is then simulated as a cylinder, whose dimension is determined by its combustion characteristics (including time to ignition, time to burn out, time to maximum flame height and maximum flame height) and the stage of its combustion (preheating, ignition, burning, or burn out). When an individual leaf flame contacts a neighboring leaf, the ignition sequence for that leaf commences, and the neighboring leaf may ignite. The flames then merge and contact surrounding leaves until burnout occurs. The flame merging submodel included semi-empirical correlations based on 2D flame merging experiments in the literature (Weng et al. 2004; Kamikawa et al. 2005). Both horizontal and vertical separation distances between leaf flames in three dimensions were considered to calculate the merged flame height. Those correlations were improved in the current model including:

$$
\frac{L_{f}}{L_{1}}=\frac{\alpha^{\prime}}{\alpha} \cdot\left(\rho_{\infty} c_{p} T_{\infty} \sqrt{g}\right)^{\beta-\beta^{\prime}} \cdot\left(\frac{\dot{Q}_{1}}{D_{1}^{5 / 2}}\right)^{\beta^{\prime}-\beta} \cdot\left(\frac{D_{1}}{D^{\prime}}\right)^{\frac{5}{2} \beta^{\prime}-1} \cdot\left(\frac{\dot{Q}_{D}}{\dot{Q}_{1}}\right)^{\beta^{\prime}}
$$

where $L_{f}$ is the merged flame height; $L_{l}$ is the solitary flame height; $\alpha$, $\beta$ ' and $\alpha, \beta$ are tuneable coefficients (prime designates merged flame); $D_{l}$ is the leaf segment diameter and $D^{\prime}$ 'is the normalized segment group characteristic diameter; $\dot{Q}_{1}$ is the heat release rate of individual leaf element combustion while $\hat{Q}_{D}$ is the segment group heat release rate. $\hat{Q}_{D} / \dot{Q}_{1}$ is currently predicted from the combustion behavior of individual leaf segments and the number of segments. This correlation is partially developed from wood crib data reported in the literature (Kamikawa et al. 2005).

A physics-based approach was established for scaling flame parameters, which included a mechanistic description of heat transfer to the leaf surface, temperature-dependent mass release, and an energy balance (Prince et al. 2017). In the current model, each leaf segment is divided into two layers, surface and interior. Species-specific multi-component one-step devolatilization models were used. Water release was tracked by a diffusion-limited model. The mass transfer was dependent on leaf temperature as well. Both convection and radiation heat fluxes were used to determine the elevated 
temperature of leaf. Finally, the heating of a leaf with the moisture evaporation was solved and the temperature history of a leaf was obtained. Based on this physics-based approach, flame parameters (end time of mass release, flame height, etc.) were scaled to match the observed fire spread conditions.

The combustion in this model was initiated by the ignition of a group of bottom corner leaf segments, which mimicked the fire front from excelsior as in the experiments. A profile of wind speed was appointed to each individual leaf segment according to its location. The combustion would terminate when there were no burning leaf segments.

\section{Results}

In total, 55 multi-shrub combustion experiments studying chamise and sagebrush were performed from 2012 to 2015 . The modeling results (flame height above the shrub $\left(\Delta z_{f, \max }\right.$ ), fraction of shrub burned $\left(X_{s}\right)$, burn time $\left(t_{\text {burn }}\right)$, flame propagation speed and flame path) were compared with experimental results. Figure 2 is an example of a flame simulation of chamise shrubs compared to the corresponding experiment. Figure 3 shows that the predicted $t_{b u r n}$ by the current model for chamise was similar to the observed behavior from experiments, which is an improvement over previous predictions for most of the experimental runs. As shown in Figure 4, the prediction of the flame height $\left(\Delta z_{f, \max }\right)$ was overestimated in the previous model especially for run 3, which was a run where it was observed experimentally that the flame was not able to successfully propagate completely through the shrub. The current model is able to predict this unsuccessful propagation but underestimates the observed maximum flame height.

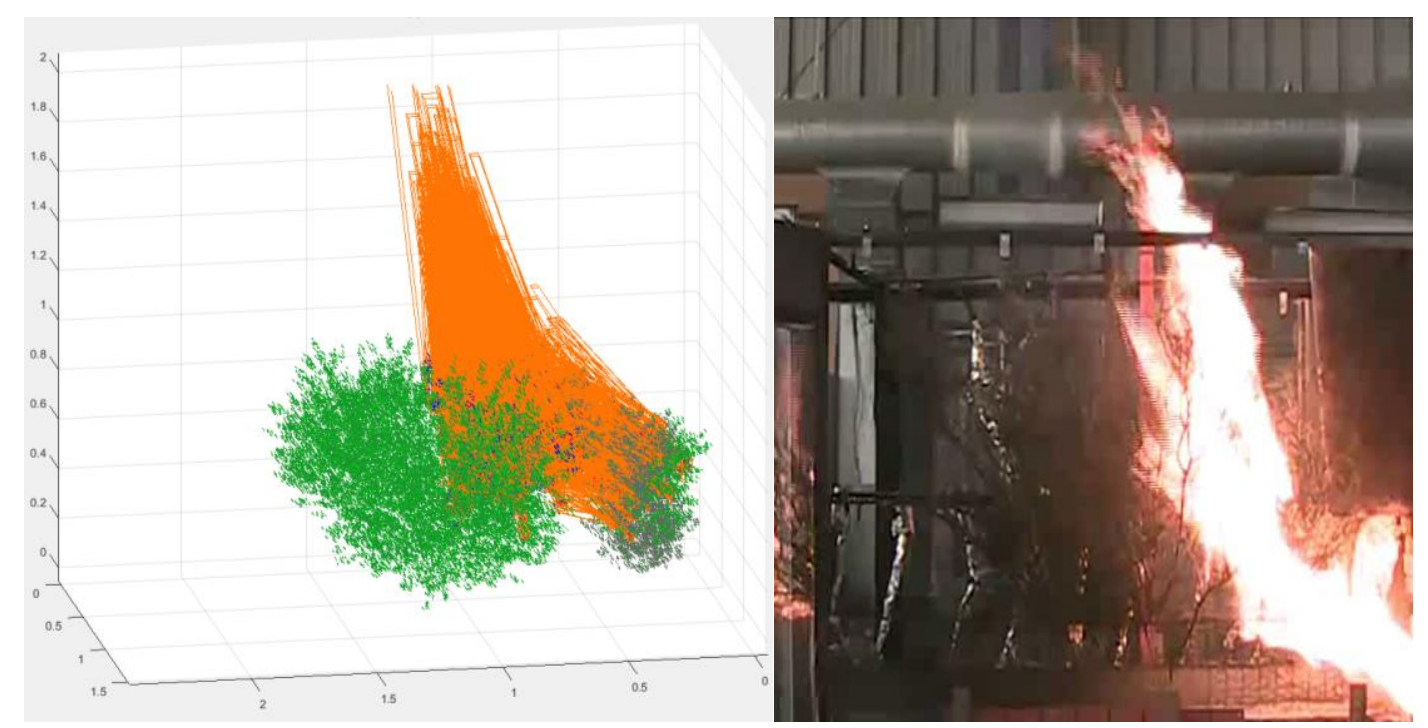

Figure 2 - Comparison of predicted flame behavior in chamise shrubs (left) using the semi-empirical shrub combustion model vs. the measured flame behavior in a wind tunnel (right). 


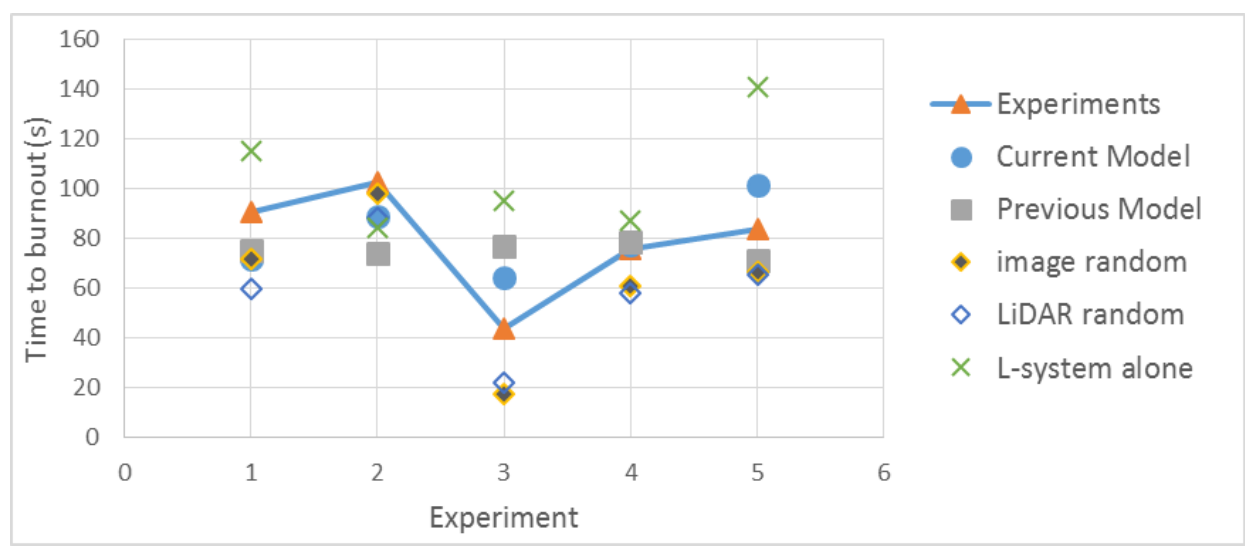

Figure 3 - Time to burnout comparison of model simulations for chamise.

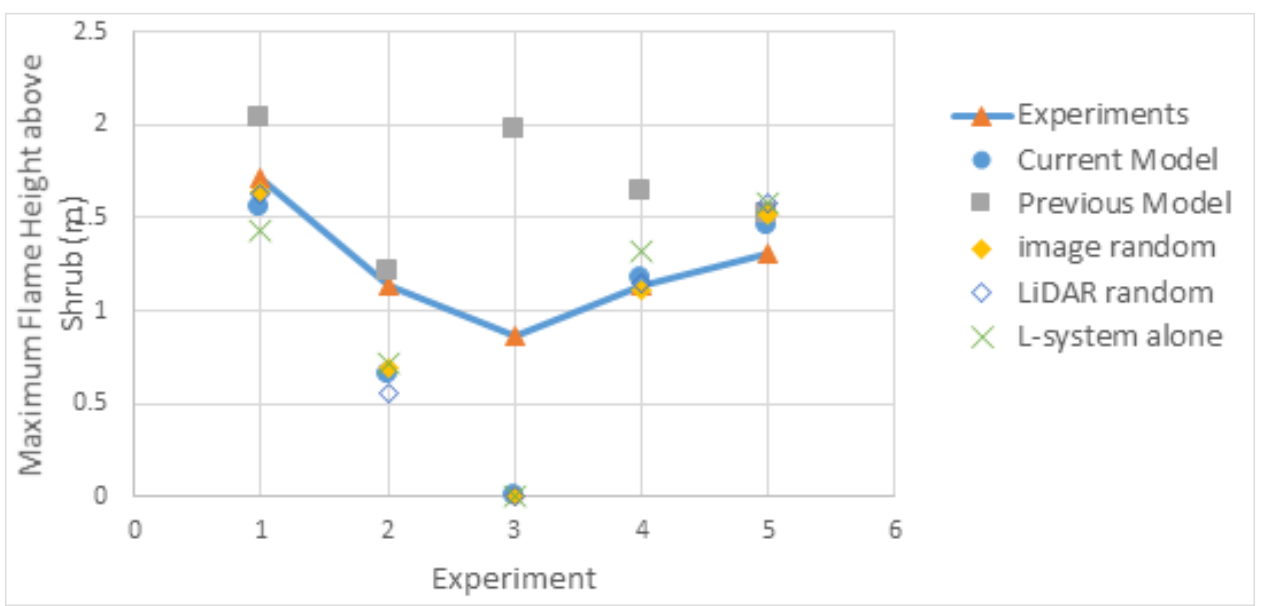

Figure 4 - Maximum flame height above the shrub comparison of model simulations for chamise.

Other less sophisticated fuel element placement approaches (random placement based on image analysis or LiDAR, and L-systems without LiDAR data) were also tested and integrated into current model. The predictions of combustion behavior with the previous fuel placement approaches are compared to the current model results (i.e., combined L-systems and LiDAR approach), which shows that the combined L-systems and LiDAR approach yielded the most consistent and best predictions of combustion behavior for most experiments.

\section{Conclusion}

Multi-shrub combustion experiments were performed in a wind tunnel facility at the Pacific Southwest Research Station in Riverside, CA. Bulk density and local fuel density were found to be two major factors in shrub flame propagation. Shrubs with high moisture content were usually observed to have a slower flame propagation rate.

Fuel element placement in the semi-empirical shrub combustion model was improved when the following were coupled: physical properties distribution, L-systems fractal theory approach, LiDAR shrub scan data and manual or image shrub measurements. More accurate flame parameters and species sensitive flame merging algorithm were developed in the semi-empirical shrub combustion model. The agreement between experimental observations and modeling results was improved. 


\section{Acknowledgements}

This work was supported by JFSP Grant 11-1-2-22 administered through USDA Forest Service PSW Research Station agreement 11-JV-11272167-054 and Brigham Young University. Special thanks to Joey Chong, Gloria Burke and Bonni Corcoran from the USDA Forest Service and Theodore Adams from the University of Montana.

\section{Reference}

Andrews PL (1986) 'BEHAVE: Fire Behavior Prediction and Fuel Modeling System- BURN Subsystem, Part 1.' USDA Forest Service, INT-194.

Finney MA (1998) 'FARSITE: Fire Area Simulator-Model Development and Evaluation.' USDA Forest Service, RMRS-RP-4.

Finney MA (2006) An overview of FlamMap fire modeling capabilities. In 'Fuels management-how to measure success: conference proceedings' pp. 28-30. (USDA Forest Service, Rocky Mountain Research Station, Fort Collins, CO)

Finney MA, Cohen JD, McAllister SS, Jolly WM (2013) On the need for a theory of wildland fire spread. International journal of wildland fire 22, 25-36.

Gallacher JR, Fletcher TH, Lansinger V, Hansen S, Ellsworth T, Weise DR (2017) Physical characteristics of shrub and conifer fuels for fire behavior models.

Kamikawa D, Weng WG, Kagiya K, Fukuda Y, Mase R, Hasemi Y (2005) Experimental study of merged flames from multifire sources in propane and wood crib burners. Combustion and Flame.

Linn RR (1997) A transport model for prediction of wildfire behavior. Ph.D. thesis, New Mexico State University.

Mell WE, Jenkins MA, Gould J, Cheney P (2007) A physics-based approach to modelling grassland fires. International Journal of Wildland Fire 16, 1-22.

Prince D, Shen C, Fletcher T (2017) Semi-empirical Model for Fire Spread in Shrubs with SpatiallyDefined Fuel Elements and Flames. Fire Technology 53, 1439-1469.

Prince DR (2014) Fire Spread in Sparse Vegetation. PhD Dissertation thesis, Brigham Young University.

Rothermel RC (1972) 'A mathematical model for predicting fire spread in wildland fuels.' USDA Forest Service, Intermountain Forest and Range Experiment Station INT-115, Ogden, Utah, USA.

Shen C (2017) Experiments and Modeling of Fire Interaction and Propagation in Big Sagebrush and Chamise Shrubs. PhD Dissertation in progress thesis, Brigham Young University.

Shen C (2018) Experiments and Modeling of Fire Interaction and Propagation in Big Sagebrush and Chamise Shrubs. PhD Dissertation in progress thesis, Brigham Young University.

Shen C, Fletcher ME, Gallacher JR, Adams T, Seielstad C, Weise D, Fletcher TH (in preparation) Geometrical Construction of Chamise and Big Sagebrush Shrubs using L-Systems Guided by LiDAR.

Weng WG, Kamikawa D, Fukuda Y, Hasemi Y, Kagiya K (2004) Study on flame height of merged flame from multiple fire sources. Combustion Science and Technology 176, 2105-2123. 